(2)

OPEN ACCESS

\title{
Three-dimensional reconstruction model in the diagnosis of Morgagni's hernia
}

\author{
Zhirong Zhang (1) , Yili Fu, Bin Hu
}

Department of Thoracic surgery, Beijing Chao-Yang Hospital, Beijing, China

\section{Correspondence to} Dr Zhirong Zhang zhangjesspumc@gmail.com

Accepted 27 January 202
Check for updates

(C) BMJ Publishing Group Limited 2021. Re-use permitted under CC BY-NC. No commercial re-use. See rights and permissions. Published by BMJ.

To cite: Zhang Z, Fu Y, Hu B. BMJ Case Rep

2021:14:e239911.

doi:10.1136/bcr-2020

239911

\section{SUMMARY}

Morgagni's hernia $(\mathrm{MH})$ can be diagnosed by different utilities, but all these methods are not always 100\% accurate. Three-dimensional (3D) reconstruction model could be helpful in better understanding the important anatomical structures. We report a case of $\mathrm{MH}$ who was once misdiagnosed as diaphragmatic eventration at the other institution and we offered laparoscopic repair according to the 3D reconstruction model. Our case highlights that 3D reconstruction model could be a useful supplementary tool in the diagnosis and preoperative assessment for patients with MH especially when it is confused in diagnosis in clinical practice.

\section{BACKGROUND}

Morgagni's hernia $(\mathrm{MH})$ is a relatively rare congenital diaphragmatic hernia making up about 3\% of all surgical hernias. ${ }^{1} \mathrm{MH}$ in adults may present with nonspecific symptoms such as chronic pain and pulmonary complaints. Although some diagnostic means could be useful in diagnosis and treatment, their use is still limited in preoperative evaluation and surgical planning. Three-dimensional (3D) reconstruction technology has made its way into clinical practice for better visualising anatomical structural details.

\section{CASE PRESENTATION}

A 74-year-old woman who presented with a 4-year history of mild dysphagia and intermittent epigastric pain, aggravating in the supine position while subsiding in the sitting, was admitted to our institution. The patient's body mass index was $19.8 \mathrm{~kg} / \mathrm{m}^{2}$. She was diagnosed as diaphragmatic eventration and underwent diaphragmatic plication through right thoracotomy incision in the other institution 2 years ago. However, the epigastric pain did not alleviate obviously and she had to continue to take painkillers and omeprazole until she was transferred to our hospital.

Enhanced CT scan of the chest and upper abdomen showed the presence of a right anteromedial diaphragmatic hernia, with a defect in diaphragm that measured $6.4 \mathrm{~cm}$ in diameter. The right lung was partly collapsed and the colon, mesenteric fat and omentum were visible within the right hemithorax (figure 1). The most likely diagnosis for this patient was $\mathrm{MH}$. To avoid the misdiagnosis of the disease, we further decided to realise the $3 \mathrm{D}$ reconstruction model of the hernia using the CT images during the preoperative evaluation. The 3D model showed the protrusion of the large bowel and mesenteric vessels through the defect of diaphragm into the chest (figure 1). Meanwhile, the diaphragm was not elevated from the lateral perspective (figure 2). According to the model $\mathrm{MH}$ was confirmed and the patient was advised to have an operation.

\section{TREATMENT}

Laparoscopic repair of diaphragmatic hernia was performed. The contents of hernia sac were colon and omentum and $\mathrm{MH}$ was further definitely confirmed during the operation. After the reduction of abdominal bowel contents, a composite mesh was offered to repair the defect. The surgical procedure was uneventful and was not affected by the previous operation fortunately.

\section{OUTCOME AND FOLLOW-UP}

The patient had an uncomplicated postoperative course and symptomatic resolution and was discharged on postoperative day 4. Follow-up thoracic CT confirmed the absence of bowel contents in the thorax and the patient remained asymptomatic at 6 and 12 months.

\section{DISCUSSION}

$\mathrm{MH}$ is the most uncommon type of diaphragmatic hernias and always discovered in female adults. ${ }^{2} \mathrm{MH}$ often develops in the right hemithorax, while the leftsided or bilateral defects are rare because of the protection provided by the heart and pericardium. In adults, they may occasionally be asymptomatic and were found on chest X-ray, but nearly $72 \%$ of the patients are symptomatic, especially when there is the possibility of visceral obstruction or strangulation. ${ }^{2}$ Therefore, early and accurate diagnosis is of great importance to avoid the undesirable serious complications and wrong treatment.

The diagnostic utilities of $\mathrm{MH}$ include chest X-ray, CT, barium enema or MRI. Although CT has emerged as the most common choice, it is not always $100 \%$
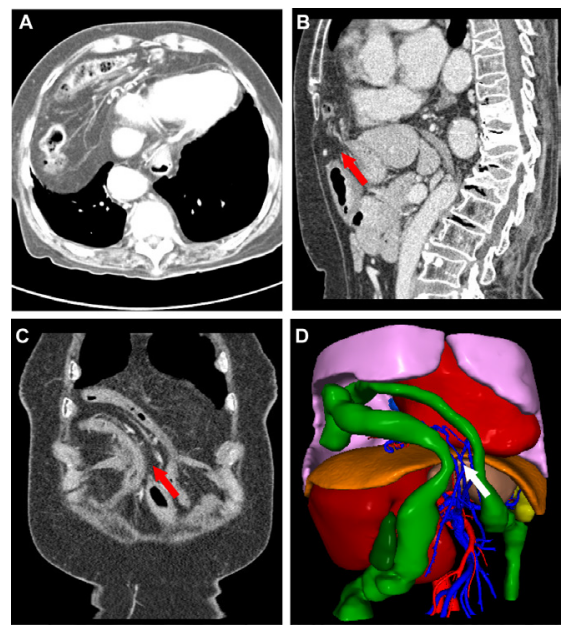

Figure 1 Preoperative CT scan and multicolour threedimensional reconstruction model showing the hernia with abdominal contents. The hernia space contains the green loop colon and the red and blue mesenteric vessels. 


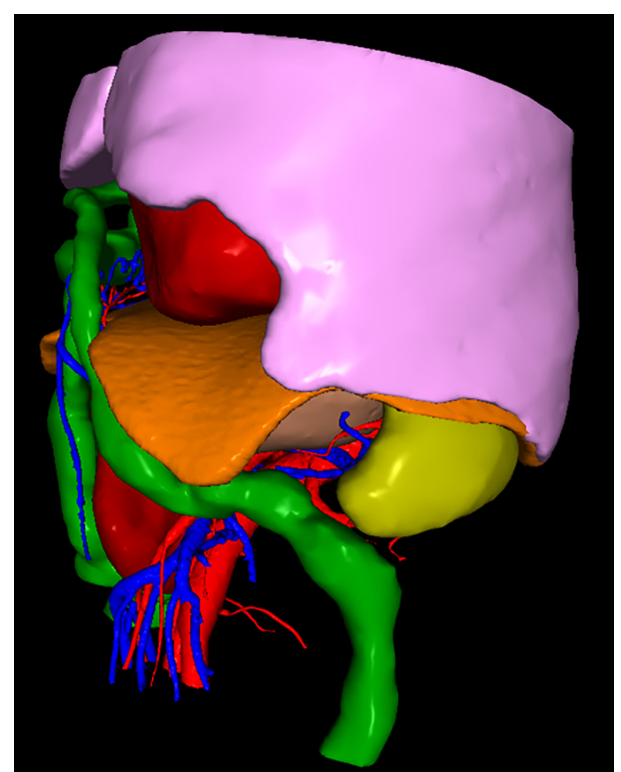

Figure 2 The diaphragm was not elevated from the lateral perspective.

accurate especially when the content of hernia sac is an anterior cardiophrenic angle abnormality with no evidence of bowel gas patterns in the chest. In this case, the 3D imaging showed the colon and omentum herniated into the chest more intuitively through the defect of diaphragm, which improves the false negative rate of CT scans for the hernia. If the 3D reconstruction model had been performed before the first surgery, the patient may not have been misdiagnosed and diaphragmatic plication via transthoracic approach could be avoided. It is really confusing and quite unimaginable that first surgery was performed on the right chest and the surgical team did not encounter any hernia sac, contents of the hernia or note the defect in the diaphragm. We once wondered whether the diaphragmatic hernia was the complication of the first surgery, but it is less likely because those chest images performed in our institution were similar with the previous CT scan in the other institution before and after the surgery. Therefore, the $3 \mathrm{D}$ reconstruction imaging is a fairly useful preoperative information to facilitate accurate diagnosis and surgical planning.

Both transthoracic and transabdominal approach to repairing the hernia could be adopted and preference varies from different researchers. ${ }^{34}$ Laparoscopic repair of $\mathrm{MH}$ has been proposed as a

\section{Learning points}

- Three-dimensional (3D) reconstruction imaging model is a useful supplement utility to avoid the misdiagnosis of Morgagni's hernia

- The 3D model could facilitate the preoperative evaluation and surgical planning for patients with Morgagni's hernia.

- It also proves helpful in better understanding the anatomical structures for residents and students in medical education.

safe and effective method with easier reduction of the hernia contents and more favourable results. With the assistance of the multicolor $3 \mathrm{D}$ reconstruction model, it is able to help to better visualise and apprehend the anatomy of hernia prior to the surgery, to take the appropriate manoeuvre for performing safer surgical procedures. Meanwhile, it proves particularly helpful in better understanding the surrounding important structures of the diaphragmatic defect zone for residents and surgeons.

Contributors The majority of the work was undertaken by the lead author ZZ. He performed the literature review and drafted the manuscript and assisted in the decision of which journal to submit to. YF and BH reviewed and edited the manuscript.

Funding The authors have not declared a specific grant for this research from any funding agency in the public, commercial or not-for-profit sectors.

Competing interests None declared.

Patient consent for publication Obtained.

Provenance and peer review Not commissioned; externally peer reviewed.

Open access This is an open access article distributed in accordance with the Creative Commons Attribution Non Commercial (CC BY-NC 4.0) license, which permits others to distribute, remix, adapt, build upon this work non-commercially, and license their derivative works on different terms, provided the original work is properly cited and the use is non-commercial. See: http://creativecommons.org/ licenses/by-nc/4.0/.

ORCID iD

Zhirong Zhang http://orcid.org/0000-0003-0741-6837

\section{REFERENCES}

1 Comer TP, Clagett OT. Surgical treatment of hernia of the foramen of Morgagni. J Thorac Cardiovasc Surg 1966;52:461-8.

2 Horton JD, Hofmann L, Hetz SP. Presentation and management of Morgagni hernias in adults: a review of 298 cases. Surg Endosc 2008;22:1413-20.

3 Kiliç D, Nadir A, Döner E, et al. Transthoracic approach in surgical management of Morgagni hernia. Eur J Cardiothorac Surg 2001;20:1016-9.

4 Karamustafaoglu YA, Kuzucuoglu M, Tarladacalisir T, et al. Transabdominal subcostal approach in surgical management of Morgagni hernia. Eur J Cardiothorac Surg 2011;39:1009-11.

Copyright 2021 BMJ Publishing Group. All rights reserved. For permission to reuse any of this content visit

https://www.bmj.com/company/products-services/rights-and-licensing/permissions/

BMJ Case Report Fellows may re-use this article for personal use and teaching without any further permission.

Become a Fellow of BMJ Case Reports today and you can:

- Submit as many cases as you like

Enjoy fast sympathetic peer review and rapid publication of accepted articles

- Access all the published articles

Re-use any of the published material for personal use and teaching without further permission

Customer Service

If you have any further queries about your subscription, please contact our customer services team on +44 (0) 2071111105 or via email at support@bmj.com.

Visit casereports.bmj.com for more articles like this and to become a Fellow 